\title{
SUATU KAJIAN YURIDIS TERHADAP PENGGUNAAN ALAT BUKTI ELEKTRONIK DALAM KEJAHATAN CYBER DALAM SISTEM PENEGAKAN HUKUM
}

\author{
Ni Made Trisna Dewi ${ }^{1)}$,Reido Lardiza Fahrial ${ }^{2)}$ \\ ${ }^{1) 2)}$ Fakultas Hukum Universitas Dwijendra Denpasar \\ Email: madetrisnadewishmh@gmail.com ${ }^{1)}$
}

\begin{abstract}
Abuse in the electronic transaction because it is formed from an electronic process, so the object changes, the goods become electronic data and the evidence is electronic. Referring to the provisions of positive law in Indonesia, there are several laws and regulations that have set about electronic evidence as legal evidence before the court but there is still debate between the usefulness and function of the electronic evidence itself, from that background in The following problems can be formulated, How do law enforcement from investigations, prosecutions to criminal case decisions in cybercrimes and How is the use of electronic evidence in criminal case investigations in cybercrimes

This research uses normative research methods that are moving from the existence of norm conflicts between the Criminal Procedure Code and ITE Law Number 19 Year 2016 in the use of evidence. The law enforcement process of the investigator, the prosecution until the court's decision cannot run in accordance with the provisions of ITE Law Number 19 of 2016, because in interpreting the use of electronic evidence still refers to Article 184 paragraph (1) KUHAP of the Criminal Procedure Code stated that the evidence used Legitimate are: witness statements, expert statements, letters, instructions and statements of the accused so that the application of the ITE Law cannot be applied effectively

The conclusion of this research is that law enforcement using electronic evidence in cyber crime cannot stand alone because the application of the Act ITE Law Number 19 Year 2016 still refers to the Criminal Code so that the evidence that is clear before the trial still refers to article 184 paragraph (1) KUHAP of the Criminal Procedure Code and the strength of proof of electronic evidence depends on the law enforcement agencies interpreting it because all electronic evidence is classified into in evidence in the form of objects as so there is a need for confidence from the legal apparatus in order to determine the position and truth of the electronic evidence
\end{abstract}

Keywords: use of evidence; electronic, cybercrime, law enforcement

\begin{abstract}
Abstrak
Penyalahgunaan didalam transaksi elektronik tersebut karena terbentuk dari suatu proses elektronik, sehingga objeknya pun berubah, barang menjadi data elektronik dan alat buktinya pun bersifat elektronik. Mengacu pada ketentuan hukum positif di Indonesia, ada beberapa peraturan perundang-undangan yang
\end{abstract}


telah mengatur mengenai alat bukti elektronik sebagai alat bukti yang sah di muka pengadilan tetapi tetap masih ada perdebatan antara kegunaan dan fungsi dari alat bukti elektronik itu sendiri, dari latar belakang tersebut di atas dapat dirumuskan masalah sebagai berikut, Bagaimana penegakkan hukum dari penyidikan, penuntutan sampai putusan perkara pidana dalam kejahatan cyber dan Bagaimanakah penggunaan bukti elektronik dalam pemeriksaan perkara pidana dalam kejahatan cyber

Penelitian ini menggunakan metode penelitian normatif yakni beranjak dari adanya konflik norma antara KUHAP dengan Undang-undang ITE Nomor 19 Tahun 2016 dalam penggunaan alat bukti. Proses penegakkan hukum dari penyidik, penuntutan sampai pada putusan pengadilan tidak dapat berjalan sesuai dengan ketentuan Undang-undang ITE Nomor 19 Tahun 2016, karena dalam melakukan penafsiran terhadap penggunaan alat bukti Elektronik masih mengacu pada Pasal 184 ayat (1) KUHAP disebutkan bahwa alat bukti yang sah adalah: keterangan saksi, keterangan ahli, surat, petunjuk dan keterangan terdakwa. sehingga penerapan Undang-undang ITE tidak dapat diterapkan secara efektiv.

Kesimpulan dari penelitian ini adalah penegakan hukum dengan menggunakan alat bukti elektronik dalam kejahatan cyber tidak bisa berdiri sendiri karena penerapan Undang-Undang ITE Nomor 19 Tahun 2016 tetap merujuk kepada KUHP sehingga alat bukti yang sah di muka persidangan tetap mengacu pada pasal 184 ayat (1) KUHAP dan Kekuatan pembuktian alat bukti elektronik tersebut tergantung dari aparat hukum dalam menafsirkannya karena semua alat bukti elektronik tersebut digolongkan ke dalam alat bukti berupa benda sebagai petunjuk sehingga diperlukan juga keyakinan dari aparat hukum agar bisa menentukan posisi dan kebenaran dari alat bukti elektronik tersebut.

Kata Kunci : penggunaan alat bukti, elektronik, dunia maya, penegakan hukum

\section{A. Pendahuluan}

Peradaban dunia pada masa saat ini ditandai dengan fenomena kemajuan teknologi informasi dan globalisasi yang berlangsung hampir di semua sector kehidupan. Perkembangan teknologi dan globalisasi tidak saja terjadi di Negara maju, tetapi juga di negara berkembang. Saat ini teknologi informasi memegang peranan yang penting dalam perdagangan dan ekonomi antar negara-negara di dunia, termasuk memperlancar arus informasi. Teknologi informasi diyakini membawa keuntungan yang besar bagi negara-negara di dunia. ${ }^{1}$ Setidaknya ada dua keuntungan yang dibawa dengan keberadaan teknologi informasi. Pertama, teknologi informasi mendorong

1 Budi Suhariyanto, 2013, Tindak Pidana Teknologi Informasi (Cyber crime) Urgensi Pengaturan dan Celah Hukumnya, Depok, PT. Rajagrafindo Persada, hlm. 1 
permintaan atas produk-produk teknologi informasi itu sendiri. Kedua, memudahkan transaksi bisnis keuangan di samping bisnis-bisnis lainnya. $^{2}$

Dalam era informasi (information age), keberadaan suatu informasi mempunyai arti dan peranan yang sangat penting didalam aspek kehidupan sehingga ketergantungan akan tersedianya informasi semakin meningkat. Perubahan bentuk masyarakat menjadi suatu masyarakat informasi (information society) memicu perkembangan teknologi informasi (information technology revolution) yang menciptakan perangkat teknologi yang kian canggih dan informasi yang berkualitas. "Kita telah berada dalam teknologi elektronik yang berbasiskan lingkungan digital, contohnya komputer pribadi, mesin fax, penggunaan kartu kredit, dan hal-hal lainnya". ${ }^{3}$

${ }^{2}$ Agus Raharjo, 2002, Cyber crime: Pemahaman dan Upaya Pencegahan Kejahatan Berteknologi, Bandung, Citra Aditya Bakti, hlm. 1

${ }^{3}$ Edmon Makarim, 2005, Pengantar Hukum Telematika, Rajagrafindo Perkasa, Jakarta, hlm. 31
Hal yang membuat internet memiliki peran yang sangat penting adalah potensi yang dimilikinya sebagai media teknologi informasi, antara lain :

1. Keberadaannya sebagai jaringan elektronik publik yang sangat besar;

2. Mampu memenuhi berbagai kebutuhan berinformasi dan berkomunikasi secara murah, cepat, dan mudah diakses, dan;

3. Menggunakan data elektronik sebagai media penyampaian pesan/data sehingga dapat dilakukan pengiriman, penerimaan, dan penyebarluasan informasi secara mudah dan ringkas. ${ }^{4}$

Di Indonesia, perkembangan teknologi informasi semakin pesat dan pengggunanya pun semakin banyak tetapi perkembangan ini tidak diimbangi dengan perkembangan produk hukumnya. Data atau informasi elektronik akan diolah dan diproses

${ }^{4}$ Jurnal Hukum dan Teknologi No. 1, 2001, "Pokok - pokok pikiran rancangan Undang-undang informasi dan transaksi elektronik (RUU-IETE)", LKHT Fakultas Hukum UI 'M.Arsyad sanusi, 2005, Hukum dan Teknologi Informasi, Tim KemasBuku, Jakarta, hlm. 120 
dalam suatu sistem elektronik dalam bentuk gelombang digital (digital information). Dengan kemajuan teknologi informasi yang pesat, diiringi dengan terjadinya perikatan antar pihak yang dilakukan dengan cara pertukaran informasi untuk melakukan transaksi perdagangan secara elektronik di ruang lingkup maya (cyber). Transaksi elektronik yang sering disebut sebagai "online contract" sebenarnya ialah transaksi yang dilakukan secara elektronik dengan memadukan jaringan (networking) dari sistem informasi berbasiskan komputer (computerbased information system) dengan sistem komunikasi yang berdasarkan atas jaringan dan jasa telekomunikasi (telecommunication-based), yang selanjutnya difasilitasi oleh keberadaan jaringan komputer global internet. ${ }^{5}$

Akan tetapi kerap timbul dampak negatif dari perkembangan teknologi informasi tersebut salah satu contohnya seperti pembobolan rekening nasabah secara online melalui dunia maya (cyber). Secara teknis, informasi dan/atau sistem informasi itu

${ }^{5}$ Edmon Makarim, 2003, Kompilasi Hukum Telematika, Rajagrafindo Persada, Jakarta, hlm. 223 sendiri sangat rentan untuk tidak berjalan sebagaimana seharusnya (malfunction), dapat diubah-ubah ataupun diterobos oleh pihak lain. Untuk melindungi kerahasiaan informasi pribadi dari ancaman pelanggaran kerahasiannya, dibutuhkan keamanan data (data security), keamanan komputer serta jaringannya. Dalam Asosiasi Teknologi Informasi Kanada pada Kongres Industri Informasi Internasional 2000 di Quebec, pernah menyatakan bahwa : "Information technology touches every aspect of human life and so can electronically enabled crime". 6

Banyak kejahatan konvensional dilakukan dengan modus operandi yang canggih sehingga dalam proses beracara diperlukan teknik atau prosedur khusus untuk mengungkap suatu kejahatan". Kegiatan perbankan yang memiliki potensi kejahatan cyber crime antara lain adalah layanan online shopping (berbelanja secara online) yang memberikan fasilitas pembayaran melalui kartu kredit (credit card ${ }^{6}$ Salman Luthan,2009, Asas dan Kriteria Kriminalisasi, Jurnal Hukum No. 1 Vol. 16 Januari, diakskes tanggal 31 Maret 2019 
fraud). Jenis kejahatan ini muncul akibat kemudahan sistem pembayaran menggunakan kartu kredit yang diberikan online shop. "Modusnya ialah pelaku menggunakan nomor kartu kredit korban untuk berbelanja di online shop Pelaku dapat saja memperoleh nomor kartu kredit korban dengan model kejahatan kartu kredit yang konvensional atau melalui dunia maya. Karena itulah, sistem hukum yang efektif telah menjadi tembok akhir bagi pencari keadilan sebagai penunjang dari penegakan hukum (law enforcement) untuk meminimumkan berbagai kejahatan di internet. ${ }^{7}$

Dengan adanya penyalahgunaan didalam transaksi elektronik tersebut karena terbentuk dari suatu proses elektronik, sehingga objeknya pun berubah, barang menjadi data elektronik dan alat buktinya pun bersifat elektronik. Mengacu pada ketentuan hukum positif di Indonesia, ada beberapa peraturan perundangundangan yang telah mengatur mengenai alat bukti elektronik (digital evidence) sebagai alat bukti yang sah di muka pengadilan. Terhadap tindak

${ }^{7}$ Krisnawati, "2006, et all”, Bunga Rampai Hukum Pidana Khusus, Pena Pundi Aksara, Jakarta, hlm. 3 pidana yang telah memiliki aturan hukum yang mengatur mengenai digital evidence (alat bukti elektronik) bukanlah suatu masalah. Namun, bagi perbuatan melanggar hukum yang belum memiliki aturan hukum khusus mengenai bukti elektronik sebagai alat bukti yang sah di muka pengadilan, maka diperlukan kecakapan aparat penegak hukum untuk melihat dan menterjemahkan bukti elektronik yang ada menjadi alat-alat bukti sebagaimana diatur dalam Pasal 184 Kitab Undang-Undang Hukum Acara Pidana sebagai alat bukti yang sah di muka pengadilan

Adapun rumusan masalah yang akan dibahas berdasarkan pemaparan latar belakang masalah di atas yakni: 1) Bagaimana penegakan hukum dari penyidikan, penuntutan sampai putusan perkara pidana dalam kejahatan cyber? dan 2) Bagaimanakah penggunaan bukti elektronik dalam pemeriksaan perkara pidana dalam kejahatan cyber? Tujuan dari karya tulis ini adalah: 1) untuk mengetahui penegakan hukum dari penyidikan, penuntutan sampai putusan perkara pidana dalam kejahatan cyber, dan 2) untuk mengetahui penggunaan bukti 
elektronik dalam pemeriksaan perkara pidana dalam kejahatan cyber.

\section{B. Metode Penelitian}

Jenis penelitian yang dipakai dalam penelitian ini adalah jenis penelitian hukum normatif yaitu melihat dan menganalisa dari sudut peraturan perundang-undangan dan norma-norma yang berlaku khususnya yang berhubungan dengan permasalahan dalam penelitian ini.

Jenis Pendekatan lebih mengarah kepada penelitian deskriptif yang merupakan metode penelitian yang berusaha menggambarkan dan menginterprestasi objek sesuai dengan Peraturan Undang-Undang. Penelitian deskriptif juga dapat membentuk teoriteori baru atau dapat memperkuat teori yang sudah ada. Di samping itu, penelitian deskriptif juga merupakan penelitian, dimana pengumpulan data untuk membandingkan pertanyaan penelitian yang berkaitan dengan keadaan dan kejadian sekarang. Disajikan dengan melaporkan keadaan objek atau subjek yang diteliti.

Dalam penulisan ini menggunakan sumber bahan hukum yaitu, bahan hukum primer, yang meliputi aturan-aturan hukum seperti Undang-Undang Nomor 19 Tahun 2016 tentang ITE , KUHP dan KUHAP dan bahan hukum sekunder yaitu berupa buku-buku, hasil penelitian yang ada hubungannya dengan dunia maya (cyber space) dan kejahatan dunia maya (cyber crime)

Teknik pengumpulan Bahan Hukum yang digunakan dalam penulisan ini adalah dengan studi kepustakaan yaitu, Peneliti membaca berbagai dokumen dan bahan-bahan pustaka yang berkaitan dengan permasalahan yang sedang di bahas dalam penelitian ini. Bahan-bahan hukum yang telah dikumpulkan selanjutnya di analisis berdasarkan tahapan-tahapan antara lain gramatikal dan sistematis , Gramatikal dimaksudkan untuk mempelajari tata bahasa yang di gunakan dalam undangundang maupun aturan terkait yang berhubungan dengan kejahatan cyber dan sistematisasi dimaksudkan mengaitkan antara bahan hukum yang satu dengan bahan hukum lainnya agar menjadi satu kesatuan yang logis. 


\section{Pembahasan}

\section{C.1. Penegakan Hukum dalam} Kejahatan Cyber

Proses penegakan hukum yang dilakukan oleh Penyidik, Jaksa Penuntut Umum dan Hakim Pengadilan negeri. Secara luas, tindak pidana siber ialah semua tindak pidana yang menggunakan sarana atau dengan bantuan Sistem Elektronik. Itu artinya semua tindak pidana konvensional dalam Kitab Undang-Undang Hukum Pidana sepanjang dengan menggunakan bantuan atau sarana Sistem Elektronik seperti pembunuhan, perdagangan orang, dapat termasuk dalam kategori tindak pidana siber dalam arti luas. Akan tetapi, dalam pengertian yang lebih sempit, pengaturan tindak pidana siber diatur dalam Undang-Undang Nomor 19 Tahun 2016 tentang Informasi dan Transaksi Elektronik.

$\begin{array}{llr}\text { Sebelum dilakukan } & \text { tindakan } \\ \text { penyidikan, } & \text { dilakukan dulu }\end{array}$
penyelidikan oleh pejabat penyelidik, dengan maksud dan tujuan mengumpulkan "bukti permulaan" atau "bukti yang cukup" agar dapat dilakukan tindak lanjut penyidikan. Mungkin penyelidikan dapat disamakan dengan pengertian "tindak pengusutan" sebagai usaha mencari dan menemukan jejak berupa keterangan dan bukti-bukti suatu peristiwa yang diduga merupakan tindak pidana.

Undang-Undang ITE sebagai pengaturan hukum siber di Indonesia, juga mengklasifikasikan tindak pidana penghinaan dan/atau pencemaran nama baik sebagai Cyber crime, apabila dilakukan di ruang maya. Terkait dengan tindak pidana penghinaan dan/atau pencemaran nama baik, Pasal 27 ayat (3) jo Pasal 45 ayat (1) UU ITE, yang jika ditulis dalam satu naskah berbunyi;

1. Setiap orang dengan sengaja dan tanpa hak mendistribusikan dan/atau mentransmisikan dan/atau membuat dapat diaksesnya Informasi Elektronik dan/atau Dokumen Elektronik yang memiliki muatan penghinaan dan/atau pencemaran nama baik, dipidana dengan pidana penjara paling lama 6 (enam) tahun dan/atau denda paling banyak Rp. 1.000.000.000,00 (satu miliar rupiah)." 

2. Setiap orang dilarang melakukan tindakan yang secara tanpa hak yang menyebabkan transmisi dari program, informasi, kode atau perintah, komputer dan atau sistem elektronik yang dilindungi Negara menjadi rusak. Setiap orang yang melanggar ketentuan sebagaimana dimaksud dalam Pasal 28, dipidana dengan pidana penjara paling lama 8 (delapan) tahun dan atau denda paling banyak Rp.2.000.000.000.,- (dua milyar rupiah). (Pasal 28 jo. Pasal 45)

\section{Setiap orang dilarang menggunakan dan atau mengakses komputer dan atau sistem elektronik secara tanpa hak atau melampaui wewenangnya, baik dari dalam maupun luar negeri untuk memperoleh informasi dari komputer dan atau sistem elektronik yang dilindungi oleh negara. Setiap orang yang melanggar ketentuan sebagaimana dimaksud dalam}

18

Pasal 29, dipidana dengan pidana penjara paling lama 8 (delapan) tahun dan atau denda paling banyak Rp.2.000.000.000.,- _dua milyar rupiah).

4. Setiap orang dilarang:

a. Menggunakan dan atau mengakses komputer dan atau sistem elektronik milik pemerintah yang dilindungi secara tanpa hak;

b. Menggunakan dan atau mengakses tanpa hak atau melampaui wewenangnya, komputer dan atau sistem elektronik yang dilindungi oleh negara, yang mengakibatkan komputer dan atau sistem elektronik tersebut menjadi rusak;

c. Menggunakan dan atau mengakses tanpa hak atau melampaui wewenangnya, komputer dan atau sistem elektronik yang dilindungi oleh masyarakat, yang mengakibatkan komputer dan atau sistem elektronik tersebut menjadi rusak; 
d. Mempengaruhi atau mengakibatkan terganggunya komputer dan atau sistem elektronik yang digunakan oleh pemerintah; Setiap orang yang melanggar ketentuan sebagaimana dimaksud dalam Pasal 30 ayat (1), Pasal 30 ayat (2), Pasal 30 ayat (3), Pasal 30 ayat (4), dipidana dengan pidana penjara paling lama 8 (delapan) tahun dan atau denda paling banyak Rp.2.000.000.000.,- （dua milyar rupiah). (Pasal 30 jo. Pasal 45).

5. Setiap orangdilarang :

a. Menggunakan dan atau mengakses komputer dan atau sistem elektronik secara tanpa hak atau melampaui wewenangnya untuk memperoleh keuntungan atau memperoleh informasi keuangan dari Bank Sentral, lembaga perbankan atau lembaga keuangan, penerbit kartu kredit, atau kartu pembayaran atau yang mengandung data laporan
19 nasabahnya. Setiap orang yang melanggar ketentuan sebagaimana dimaksud dalam Pasal 31 ayat (1), dipidana dengan pidana penjara paling lama 10 (sepuluh) tahun dan atau denda paling banyak Rp.2.000.000.000.,- $\quad$ (dua milyar rupiah).

b. Menggunakan dan atau mengakses dengan cara apapun kartu kredit atau kartu pembayaran milik orang lain secara tanpa hak dalam transaksi elektronik untuk memperoleh keuntungan. Setiap orang yang melanggar ketentuan sebagaimana dimaksud dalam Pasal 31 ayat (2), dipidana dengan pidana penjara paling lama 10 (sepuluh) tahun dan atau denda paling banyak Rp.2.000.000.000,- _dua milyar rupiah).

6. Setiap orang dilarang menggunakan dan atau mengakses komputer dan atau sistem elektronik Bank Sentral, 
lembaga perbankan dan atau lembaga keuangan yang dilindungi secara tanpa hak atau melampaui wewenangnya, untuk disalah gunakan, dan atau untuk mendapatkan keuntungan daripadanya. Setiap orang yang melanggar ketentuan sebagaimana dimaksud dalam Pasal 32, dipidana dengan pidana penjara paling lama 10 (sepuluh) tahun dan atau denda paling banyak Rp.2.000.000.000,- (dua milyar rupiah).

7. Setiap orang dilarang:

a. Menyebarkan, memperdagangkan, dan atau memanfaatkan kode akses (password) atau informasi yang serupa dengan hal tersebut, yang dapat digunakan menerobos komputer dan atau sistem elektronik dengan tujuan menyalahgunakan yang akibatnya dapat mempengaruhi sistem elektronik Bank Sentral, lembaga perbankan dan atau lembaga keuangan,
20

serta perniagaan di dalam dan luar negeri. Setiap orang yang melanggar ketentuan sebagaimana dimaksud dalam Pasal 33 ayat (1), dipidana dengan pidana penjara paling lama 10 (sepuluh) tahun dan atau denda paling banyak Rp.2.000.000.000,- (dua milyar rupiah). (Pasal 33 jo Pasal 47).

b. Menyebarkan, memperdagangkan, dan atau memanfaatkan kode akses (password) atau informasi yang serupa dengan hal tersebut, yang dapat digunakan menerobos komputer dan atau sistem elektronik dengan tujuan menyalahgunakan

komputer dan atau sistem elektronik yang digunakan atau dilindungi oleh pemerintah. Setiap orang yang melanggar ketentuan sebagaimana dimaksud dalam Pasal 33 ayat (2), dipidana dengan pidana penjara paling lama 8 
(delapan) tahun dan atau denda paling banyak Rp.2.000.000.000,- $\quad$ (dua milyar rupiah). (Pasal 33 jo. Pasal 45).

8. Setiap orang dilarang melakukan perbuatan dalam rangka hubungan internasional dengan maksud merusak komputer atau sistem elektronik lainnya yang dilindungi negara dan berada di wilayah yurisdiksi Indonesia. Setiap orang yang melanggar ketentuan sebagaimana dimaksud dalam Pasal 34 dipidana dengan pidana penjara paling lama 8 (delapan) tahun dan atau denda paling banyak Rp.2.000.000.000.,(dua milyar rupiah) ${ }^{8}$

\section{C.2. Kekuatan Pembuktian Dalam Perkara Pidana Dalam Kejahatan Cyber}

Dalam menangani kasus cyber crime aparat penegak hukum harus

\footnotetext{
${ }^{8}$ Barda Nawawi Arief, 2001, Masalah Penegakan Hukum dan Kebijakan Penanggulangan Kejahatan, PT. Citra Aditya Bakti, Bandung, hal. 33
}

memperhatikan mengenai alat bukti digital yang digunakan oleh pelaku dalam melakukan perbuatannya. Karena alat bukti digital tersebut mempunyai kedudukan yang sangat penting dalam rangka proses pembuktian di Persidangan Pengadilan. Dari alat bukti digital tersebut yang nantinya juga akan menentukan apakah perbuatan yang dilakukan oleh terdakwa benar bersalah menurut hukum, Pertimbangan hakim dalam mengungkap fakta di persidangan dengan menggunakan alat bukti digital ialah pada Pasal 5 ayat (1) UndangUndang No. 19 tahun 2016 tentang Informasi dan Transaksi Elektronik menjelaskan "Informasi Elektronik dan/atau Dokumen Elektronik dan/atau hasil cetaknya merupakan alat bukti hukum yang sah".

Untuk mengungkap alat bukti digital maka hakim memerlukan saksi ahli dalam menjelaskan alat bukti tersebut seperti yang tercantum pada Pasal 1 angka 1 dan angka 4 yang menjelaskan "angka 1 : Informasi Elektronik adalah satu atau sekumpulan data elektronik, termasuk tetapi tidak terbatas pada tulisan, suara, 
gambar, peta, rancangan, foto, electronic data interchange (EDI), surat elektronik (electronic mail), telegram, teleks, telecopy atau sejenisnya, huruf, tanda, angka, Kode Akses, simbol, atau perforasi yang telah diolah yang memiliki arti atau dapat dipahami oleh orang yang mampu memahaminya,

Sehingga dapat kita ketahui kedudukan alat bukti digital dalam putusan Hakim dalam pengungkapan fakta di persidangan dalam rangka menemukan kebenaran materiil, Majelis Hakim membutuhkan alat bukti digital dalam perkara cyber crime dan peran saksi ahli dalam menguatkan peran kedudukan alat bukti digital tersebut, karena dalam Pasal 1 angka 1 dan angka 4 Undang-Undang No. 19 tahun 2016 menjelaskan bahwa Informasi Elektronik dan Dokumen Elektronik hanya bisa dipahami oleh orang yang mampu memahaminya, orang yang mampu memahaminya berarti mempunyai keahlian dalam bidang Informasi dan Transaksi Elektronik, dalam hal ini disebut saksi ahli, Karena kedudukan alat bukti digital bersifat petunjuk dan dapat mempengaruhi pertimbangan hakim untuk membuat putusan.

\section{Simpulan dan Saran}

\section{D.1. Kesimpulan}

Berdasarkan hasil pembahasan di atas, penulis berkesimpulan sebagai berikut :

1. Proses penegakkan hukum dari penyidik, penuntutan sampai pada putusan pengadilan tidak dapat berjalan sesuai dengan ketentuan Undang-undang ITE Nomor 19 Tahun 2016, karena dalam melakukan penafsiran terhadap penggunaan alat bukti Elektronik masih mengacu pada KUHP Pasal 184 ayat (1) Kitab Undang-Undang Hukum Acara Pidana ('KUHAP") disebutkan bahwa alat bukti yang sah adalah: keterangan saksi, keterangan ahli, surat, petunjuk dan keterangan terdakwa. Dalam sistem pembuktian hukum acara pidana, hanya alat-alat bukti yang sah menurut undangundang yang dapat dipergunakan untuk pembuktian, sehingga penerapan Undang-undang ITE tidak dapat diterapkan secara efektif dan tidak dapat 
berdiri sendiri dalam proses penegakan hukumnya

2. Penggunaan bukti elektronik dalam pemeriksaan perkara pidana dalam kejahatan cyber crime berupa alat elektronik (cyber) antara lain : laptop , handphone, rekaman CCTV, rekaman suara (voice recorder), rekaman percakapan telephone, Screen Capture percakapan di aplikasi pesan (contoh Whatsup), Screen Capture percakapan maupun foto dan video di social media (contoh facebook), Email, kartu atm/kartu kredit yang dipalsukan, Nomer rekening, dan semua yang berhubungan dengan kejahatan (cyber crime) yang terjadi di dunia maya (cyber space), dan semua memiliki kekuatan pembuktian masing-masing di dalam penyidikan maupun di dalam persidangan tergantung dari keakuratan alat bukti elektronik tersebut dan tergantung pula dari keaslian dari alat bukti elektronik tersebut semua alat bukti
23

digolongkan ke dalam alat bukti berupa benda sebagai petunjuk dalam KUHP atau KUHAP, sehingga hakim tidak hanya menafsirkan Undangundang ITE Nomor 19 Tahun 2016 saja untuk mengambil keputusan.

\section{D.2 Saran}

Dari kesimpulan di atas, penulis mengajukan dua saran sebagai berikut:

1. Kepada Bapak atau Ibu Hakim di Pengadilan Republik Indonesia, Penulis setuju bahwa penegakan hukum dalam proses penyelidikan, penyidikan sampai pada pengambilan keputusan hakim dalam mengambil keputusan tidak hanya bisa mengacu pada alat bukti dari undang-undang Nomor 19 Tahun 2016, namun juga mengacu pada alat bukti sesuai dengan ketentuan KUHP, karena alat bukti yang ada dalam UUITE sebagai perluasan dari KUHP, tetapi disini juga sangat di butuhkan keyakinan hakim dalam menentukan apakah alat bukti elektronik tersebut bisa 
membuktikan kebenaran atas dugaan unsur pidana, mengingat bukti kejahatan cyber crime tersebut berbentuk digital tak berwujud tetap den terjadi di dunia maya (cyber space)

Kepada Bapak atau Ibu penyidik di Kepolisian Republik Indonesia di harapkan bisa mendapatkan lagi pelatihan maupun pedoman/panduan yang lebih detail agar bisa lebih memahami secara mendalam tentang penggunaan alat bukti elektronik, pada bagian mana yang bisa terdapat dugaan unsur pidana maupun tidak dan alat bukti elektronik seperti apa saja (jenis) yang bisa di terapkan atau di gunakan dalam pemeriksaan, agar alat bukti elektronik tersebut bisa benar-benar berguna dan bersuara untuk membuktikan suatu kebenaran pada saat hakim melakukan pembuktian di dalam persidangan.

\section{Daftar Pustaka}

\section{$\underline{\text { Buku }}$}

Agus Raharjo, 2002, Cyber crime Pemahaman dan Upaya Pencegahan Kejahatan Berteknologi, Citra Aditya Bakti, Bandung.
24

Budi Suhariyanto, 2013, Tindak Pidana Teknologi Informasi (Cyber crime) Urgensi Pengaturan dan Celah Hukumnya, Depok, PT. Rajagrafindo Persada.

Barda Nawawi Arief, 2001, Masalah Penegakan Hukum dan Kebijakan Penanggulangan Kejahatan, PT. Citra Aditya Bakti, Bandung.

Edmon Makarim, 2003, Kompilasi Hukum Telematika, Rajagrafindo Persada, Jakarta.

Krisnawati, "2006, et all”, Bunga Rampai Hukum Pidana Khusus, Pena Pundi Aksara, Jakarta.

Salman Luthan, 2009, Asas dan Kriteria Kriminalisasi, Jurnal Hukum No. 1 Vol. 16 Januari.

\section{Jurnal}

Jurnal Hukum dan Teknologi No. 1, 2001, "Pokok-pokok pikiran rancangan Undang-undang informasi dan transaksi elektronik (RUU-IETE)", LKHT Fakultas Hukum UI 'M.Arsyad sanusi, 2005, Hukum dan Teknologi Informasi, Tim KemasBuku, Jakarta

\section{Peraturan Perundang-Undangan}

Undang-Undang Dasar Negara Republik Indonesia Tahun 1945

Kitab Undang-Undang Hukum Pidana (KUHP) 
Jurnal Hukum Saraswati (JHS) Volume. 03, Nomor 02, (2021)

ISSN (Cetak) : 2715-758X ISSN (Online): 2720-9555

DOI: https://doi.org/10.36733/jhshs.v2i2

https://e-journal.unmas.ac.id/index.php/JHS

Kitab Undang-Undang Hukum Acara Pidana (KUHAP)

Undang-Undang Nomor 19 Tahun

2016 tentang Informasi dan

Transaksi Elektronik 